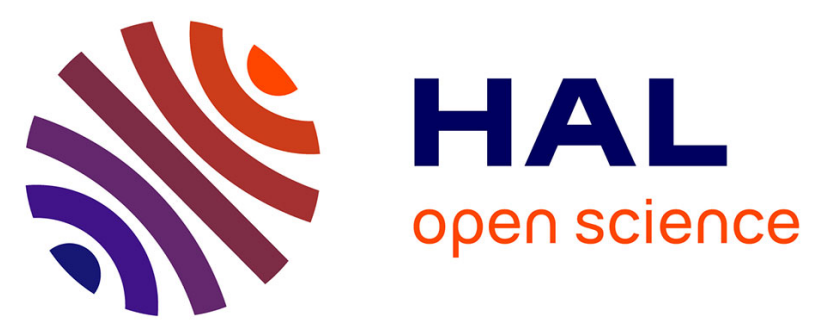

\title{
Metamorphic core complexes vs. synkinematic plutons in continental extension setting: insights from key structures (Shandong Province, eastern China)
}

Nicolas Charles, Charles Gumiaux, Romain Augier, Yan Chen, Rixiang Zhu, Wei Lin

\section{To cite this version:}

Nicolas Charles, Charles Gumiaux, Romain Augier, Yan Chen, Rixiang Zhu, et al.. Metamorphic core complexes vs. synkinematic plutons in continental extension setting: insights from key structures (Shandong Province, eastern China). Journal of Southeast Asian earth sciences, 2011, 40, pp.261-278. 10.1016/j.jseaes.2010.07.006 . insu-00509062

\section{HAL Id: insu-00509062 \\ https://hal-insu.archives-ouvertes.fr/insu-00509062}

Submitted on 11 Aug 2010

HAL is a multi-disciplinary open access archive for the deposit and dissemination of scientific research documents, whether they are published or not. The documents may come from teaching and research institutions in France or abroad, or from public or private research centers.
L'archive ouverte pluridisciplinaire HAL, est destinée au dépôt et à la diffusion de documents scientifiques de niveau recherche, publiés ou non, émanant des établissements d'enseignement et de recherche français ou étrangers, des laboratoires publics ou privés. 
Metamorphic core complexes vs. synkinematic plutons in continental extension setting: insights from key structures (Shandong Province, eastern China)

Nicolas CHARLES ${ }^{1, *}$, Charles GUMIAUX ${ }^{1}$, Romain AUGIER ${ }^{1}$, Yan CHEN $^{1,2}$, Rixiang $\mathrm{ZHU}^{2}$, Wei $\mathrm{LIN}^{2}$

1. Université d'Orléans - INSU/CNRS

Institut des Sciences de la Terre d'Orléans (ISTO)

1A rue de la Férollerie

45071 Orléans Cedex 2

France

2. Institute of Geology and Geophysics, Chinese Academy of Sciences

Beituchengxi Road 19

P.O. Box 9825

Beijing 100029

China

*Corresponding author: nicolas.charles@univ-orleans.fr; nicolas.charlesmoreau@yahoo.fr

\begin{abstract}
Continental extension is an important geodynamical process mostly diagnostic of a peculiar behaviour of the crust accommodated by geological structures that highlight these specific conditions in the crust. Though a Metamorphic Core Complex (MCC) reveals a much stronger crustal extension than a synkinematic pluton, the nature of those two structures implies different implications in terms of crustal extension mechanisms and geodynamic significations. In eastern Asia, a major continental extensional event occurred during Mesozoic and early Cenozoic times. The resulting various extensional events described in previous studies consist in large intracontinental basins, important volcanism, emplacement of plutons in the upper-crust and exhumation of MCCs. An efficient description of MCCs and
\end{abstract}


plutons in eastern Asia is essential to discriminate important differences of those two structures in terms of strain amount undergone by continental crust and geodynamic significations. In that way, an integrated structural and geophysical study has been realized to precisely discriminate the structure in the Jiaodong Peninsula (Shandong Province, eastern China), previously regarded as simple sheared plutons. A succession of three main stages have been identified all pertaining to a NW-SE extensional setting: (1) the exhumation of the Late Jurassic-Early Cretaceous Linglong MCC below the SE-dipping Linglong detachment fault, (2) the emplacement of the Guojialing syntectonic pluton below the N-dipping extensional Guojialing intracrustal shear zone (130-124 Ma) and (3) a penetrative brittle normal faulting associated with gold mineralizations ( 120 Ma). As a result, the maximum amount of extension in Jiaodong Peninsula, characterized by partially-melted lower to middle crust upward into the Linglong MCC should be revised to Late Jurassic-Early Cretaceous period.

Key-words: Mesozoic extension, eastern Asia, Metamorphic Core Complex, synkinematic pluton.

\section{Introduction}

Extension of continental areas represents one of the most important geodynamical processes. Specific crustal geological structures which accommodate deformation can highlight the role played by strain rate, thermal conditions or lithosphere's envelopes mean composition during an extensional event. In particular, "Metamorphic Core Complex" (MCC) which has been firstly defined in the Basin and Range Province and then recognized in the Aegean has been interpreted as the result of a strong tectonic denudation occurring in those areas (e.g. Davis and Coney, 1979; Crittenden et al., 1980; Wernicke, 1980; Lister and Davis, 1989; Gautier et al., 1990; Sokoutis et al., 1993). In fact, exhumation and deformation of middle to lower crustal rocks and development of master detachment faults lead to consider a 
large amount of extension for the whole crust. Moreover, extension processes can be favoured by partial melting and widespread magmatism that strongly weakens the lithosphere, emphasizing deformation and strain localization (Reynolds and Rehrig, 1980; Coney and Harms, 1984; Lynch and Morgan, 1987). In such an extensive setting, synkinematic plutons that can emplace along major shear zones in the upper crust are of efficient markers to study crustal deformation (e.g. Cloos, 1925; Balk, 1937; Ramsay, 1989). Nevertheless, although symptomatic of magmas uprising through the crust, emplacement of plutons does not necessarily reveal an extensive setting as shown for example in the Variscan Central Armorican Shear Belt (e.g. Berthé et al., 1989; Roman-Berdiel et al., 1998). Thus, MCC exhumation well requires much stronger crustal extension than synkinematic pluton emplacement does, which implies different mechanisms and geodynamic interpretations.

In eastern Asia, a major continental extension event has been evidenced during Late Mesozoic and Cenozoic times (e.g. Ren et al., 2002; Meng, 2003; Lin and Wang, 2006; Zhai et al., 2007). Most authors consider the numerous extensional field evidences described for a long time throughout eastern Asia as developed in the frame of this major extensional event. In fact, widespread sedimentary basins (e.g. Songliao, Erlian, East Gobi, Yingen, Hailar, Bohai basins; Allen et al., 1998; Ren et al., 2002; Hu et al., 2007; Li et al., 2007), volcanic and plutonic rocks (e.g. Great Xing'an Range; Fan et al., 2001; Wu et al., 2005a, 2005b; Wang et al., 2006; Wu et al., 2007), and the development of MCCs (e.g. Yunmengshan, Wugongshan, Yiwulüshan, Yagan-Onch Hayrhan, South Liaoning Peninsula; Davis et al., 1996; Faure et al., 1996; Ma et al., 1999 and Darby et al., 2004; Webb et al., 1999; Liu et al., 2005 and Lin and Wang, 2006, respectively) constitute field evidences of this regional-scale extension.

It is noteworthy that several disputed models have been proposed as geodynamical causes to explain this major continental lithospheric extensional event: (1) back-arc extension 
induced from Palaeo-Pacific plate subduction (Li, 2000; Ratschbacher et al., 2000; Zhou and Li, 2000; Ren et al., 2002; Wu et al., 2005a, 2005b; Zhou et al., 2006), (2) post-orogenic collapse (Meng, 2003), (3) lithospheric delamination (Lin and Wang, 2006), (4) mantle plume (Wilde et al., 2003; Wu et al., 2005a), (5) collision between India and Asia (Menzies et al., 1993; Liu et al., 2004).

In eastern Asia, the importance of the extension has been firstly described by the recognition of MCC (Davis et al., 1996) which has been settled by the exhumation of footwall mylonites and synextensional volcanic rocks erupted within supra-detachment basins at the period of 110-130 Ma (e.g. Davis et al., 1996; Webb et al., 1999; Darby et al., 2004; Lin et al., 2007). Besides, recent radiochronologic time-constraints of igneous rocks in North China highlight a peak of plutonism around 120-130 Ma leading several authors to consider this period as the peak of extension rate (Wu et al., 1999, Zhou et al., 2003; Wu et al., 2005a, 2005b; Sun et al., 2007). Nevertheless, the link made between occurrence of plutons and extension paroxysm is not straightforward. The different crustal-scale structures observed in the area (i.e. MCCs vs. plutons) do not mark the same strain amount and it is thus crucial to perform precise structural analysis of the dated bodies in order to better constrain the deformation rate variations with time and to understand its geodynamic history and, consequently, the mechanism implied for this lithospheric extension.

In the Jiaodong Peninsula (eastern China; Fig. 1), the Linglong and Guojialing massifs constitute a case study where such approach can be applied. There, two main igneous massifs display apparent resemblances in term of map shapes and overall structures. The reappraisal of these two massifs at the light of structural observations, geophysical measurements and recent a compilation of radiochronologic data will offer more precise informations on the nature of these massifs. This study brings new insights on the evolution of the extension in eastern China and permits to discuss the peculiar modes of extension in this area. 


\section{The Linglong and Guojialing massifs as geological witnesses of Late Mesozoic extension in the Jiaodong Peninsula (NE China)}

The Jiaodong Peninsula (Shandong Province, NE China) is located along the southeastern margin of the North China Craton (NCC) and at the western margin of the Pacific Plate. It is bounded to the west by the NNE-trending crustal-scale Tancheng-Lujiang (also called Tan-Lu) fault and to the SE by the Sulu ultrahigh-pressure metamorphic belt (Fig. 1a). The Jiaodong Peninsula can be divided into four main lithological groups (Fig. 1b): (1) Late Archaean gneisses, granulites, amphibolites and micaschists belonging to the Jiaodong Group; (2) Palaeoproterozoic mafic to felsic volcanic and sedimentary rocks metamorphosed to amphibolite-granulite facies (Jinshan and Fengzishan Groups); (3) Late Jurassic and Early Cretaceous plutonic and metamorphic rocks (e.g. Linglong, Luanjiahe, Kunyushan, Guojialing, Weideshan, Aishan and Haiyang massifs); and (4) Cretaceous volcanosedimentary rocks that constitute the Jiaolai basin (Fig. 1b; SBGMR, 1991).

The Jiaodong Peninsula is well-known as the largest granitoids-hosted gold province in China, with estimated reserves exceeding 850 tons (>30 Moz), and numerous specific geological studies have thus been made in this region (e.g. Lü and Kong, 1993; Liu et al., 1994; Wang et al., 1998; Zhou and Lü, 2000; Li et al., 2003; Lu et al., 2007). This work focuses on the western part of the Jiaodong Peninsula: the Linglong and Guojialing massifs (Fig. 1b).

Located in the Pingdu-Laizhou-Zhaoyuan area, the Linglong massif is NNE-SSW oriented and is $\sim 60 \mathrm{~km} \mathrm{x} \sim 30 \mathrm{~km}$ (see "LL" on Fig. 1b). According to previous studies (e.g. Sang, 1984; SBGMR, 1991) and our own field works, the Linglong massif essentially exposes migmatitic and granitic rocks. At outcrop-scale, continuous transitions from migmatites to anatectic granite have often been observed as well as interfingering of migmatitic rocks with 
granitic network. In this massif, granitic rocks have been well studied (e.g. Sang, 1984); they are essentially composed of a medium-grained and grey-coloured monzogranite, which is metaluminous to slightly peraluminous and mainly composed of plagioclase, K-feldspar, quartz and biotite associated with garnet and muscovite. Recent geochronological studies reveal SHRIMP U/Pb zircon Late Jurassic ages of 160-150 Ma interpreted as crystallisation age of these granitic rocks (Fig. 2; Miao et al., 1998; Wang et al., 1998; Luo et al., 1999). From the $\mathrm{Sr}-\mathrm{Nd}-\mathrm{Pb}$ isotope ratios of $0.710498-0.712286$ and $-20.46--21.12$ for $\mathrm{I}_{\mathrm{Sr}}(\mathrm{t})$ and $\varepsilon_{\mathrm{Nd}}(\mathrm{t})$, respectively, Zhou et al. (2003) have shown that the material source may be characterized by "old crustal components". Moreover, in the Linglong massif, others granitoids have also been recognized. They are characterized by high proportions of reddishpinkish K-feldspar phenocrysts, minor biotite and similar abundance between quartz and plagioclase with graphic and miarolitic textures. Those granitoids have been dated by wholerock K-Ar method at 117-84 Ma (e.g. Aishan pluton, Fig. 2; SBGMR, 1991) and are intrusive within the Late Jurassic granite and migmatites. The Linglong massif is surrounded by Late Archaean Jiaodong Group and Early Proterozoic Jingshan Group rocks. Based on an exhaustive structural analysis as well as on a geophysical bulk geometry modelling, the present study shows that the Linglong massif is a Metamorphic Core Complex (MCC) comprising a lower unit, made of migmatitic and associated granitic rocks, separated to the east by a master detachment zone, from an upper unit composed of the Late Archaean and Early Proterozoic upper crustal rock units (see details in the following part 3).

Lying to the north of the Linglong massif, the Guojialing massif (see "GJL" on Fig. 1b) is entirely composed of granodiorite, generally porphyric, with quartz, biotite, plagioclase and amphibole (locally higher than $25 \%$ content). This granodiorite is dated by SHRIMP $\mathrm{U} / \mathrm{Pb}$ zircon method at 130-126 Ma (Fig. 2; Guan et al., 1998; Wang et al., 1998) and by ${ }^{40} \mathrm{Ar} /{ }^{39} \mathrm{Ar}$ biotite method at $124.0 \pm 0.4,124.2 \pm 0.3$ and 124.5 $\pm 0.4 \mathrm{Ma}$ (Fig. 2, Li et al., 
2003). The Sr-Nd-Pb isotope ratios are 0.709361-0.711419 and $-15.07--17.50$ for $\mathrm{I}_{\mathrm{Sr}}(\mathrm{t})$ and $\varepsilon_{N d}(t)$, respectively, which reveal a material source of young enriched lithospheric mantle components (Zhou et al., 2003). Based upon unambiguous cross-check criteria of granodioritic dykes, its intrusive relationship with the Linglong massif rocks, to the south, has been described in literature, (Chen and Zhu, 1993; Lü and Kong, 1993; Liu et al., 1994). The present study shows that the Guojialing massif is a synkinematic pluton roofed by an extensional intracrustal shear zone.

Besides, the Linglong and Guojialing massifs are the principal host of gold mineralization (80\% of the gold deposits in Jiaodong; Wang et al., 1998; Zhou and Lü, 2000; Li et al., 2003; Zhou et al., 2003; Mao et al., 2008). Gold deposits are mainly characterized by massive quartz veins and disseminations/stockworks close to brittle faults (Zhou and Lü, 2000). Mineralization event is well constrained by ${ }^{40} \mathrm{Ar} /{ }^{39} \mathrm{Ar}$ ages on sericite and muscovite at around $120 \mathrm{Ma}$ (Fig. 2; Li et al., 2003; Zhang et al., 2003).

\section{Ductile deformation analysis within the Linglong and Guojialing massifs}

\subsection{The Linglong massif}

\subsubsection{Upper unit (Early Proterozoic and Late Archaean) rocks}

The Linglong massif is surrounded by Precambrian units comprising the Late Archaean Jiaodong Group and Early Proterozoic Jingshan Group rocks (Li and Yang, 1993; Fig. 3a). The Jiaodong Group is mainly composed of sedimentary and mafic to felsic volcanic rocks that have been metamorphosed in amphibolite to granulite-facies. This sequence is dated at $2665 \pm 9 \mathrm{Ma}$ by $\mathrm{U} / \mathrm{Pb}$ zircon method (Qiu, 1989). The Jingshan Group consists of low-grade metasedimentary rocks (e.g. marble and schist) dated at 2.48-2.03 Ga (U/Pb on zircon ages; Yang and Lü, 1996) and lying unconformably on the Jiaodong Group. According to petrological and geochemical studies, both Precambrian sequences, deriving 
from Trondhjemite-Tonalite-Granodorite (TTG) and basaltic volcanic rocks (SBGMR, 1991; Yang and Lü, 1996), were metamorphosed during Palaeoproterozoic orogens (An, 1990; Lü and Kong, 1993; Zhang et al., 1994).

According to our field observations, rocks of the Jiaodong Group exhibit gneissic and migmatitic foliation (Fig. 3a) which can be regarded as Precambrian in age (see references above). Marbles pertaining to Jingshan Group display bedding strikes oblique to the eastern border of the Linglong massif (Fig. 3a) and are weakly deformed. Deformation is only well marked at the vicinity (i.e. less than $100 \mathrm{~m}$ ) with the eastern border of the Linglong massif, exhibiting crenulation within foliated rocks, drag folds and N30-40E trending faults.

\subsubsection{Lower unit (Late Jurassic granite and migmatites)}

Structures described below are illustrated in Figures 4 and 5. Within the Linglong massif, mapping of the contacts in between migmatites and granitic rocks displays N30-40E orientations, parallel to the cartographic long axis of the massif, as shown on Figure 3a. At outcrop scale, granitic rocks display isotropic to weakly oriented fabrics within the core of the massif. The western boundary of the Linglong massif is characterized by (1) unstrained or weakly deformed plutonic rocks and (2) granitic dykes cutting across inherited fabrics of the enclosing Archaean rocks (Fig. 4a). In contrast, the eastern border exhibits deformation within granitic and migmatitic rocks with a clearly increasing intensity from core to rim. Foliation is particularly well marked by a general flattening and often underlined by biotites flakes. It trends roughly parallel to the eastern and southern borders of the massif (Fig. 3a), dips to the east and straightening up from $\mathrm{W}$ to $\mathrm{E}$ (Figs. 5a and 5b) In contrast, mineral and stretching lineations, marked by biotite and quartz aggregates, reveal consistent N120-140E trend throughout the massif, except for local deviations in southeastern part (Fig. 3a). Toward this boundary, the migmatitic fabrics become parallel to the foliation orientation; segregated 
leucosomes and melanosomes form regular metre-scale layering defining structural surfaces (Fig. 4b). Those particular structures have already been observed in previous studies and defined as "unusual gneissic texture" regarded as solely resulting from partial melting processes, without taking into account the finite strain (SBGMR, 1991; Lu et al., 1996; Yang and Lü, 1996; Wang et al., 1998; Zhou and Lü, 2000). At map scale (Fig. 3a), the Linglong massif displays an elongated shape. The general attitude of the foliation planes (and the associated layering within the migmatites) as well as its internal strain gradient shows that the structure of the Linglong massif is consistent with a dome-like structure. Besides, in the core and to the SW of the Linglong dome, the reddish-pinkish Cretaceous granodiorite massifs, displaying a systematic isotropic texture and cutting across granitic and migmatitic fabrics, are clearly intrusive within the dome (Figs. $3 a$ and $5 b$ ).

\subsubsection{The Linglong detachment fault (LDF)}

When approaching to the eastern boundary of the Linglong dome, simple shear criteria are increasingly well expressed. At outcrop-scale, drag folds, sigmoidal feldspars and sigmoidal foliation planes associated with low-angle shear planes indicate an overall and systematic top-to-the SE sense of shear (Figs. 3a and 4c). From W to E, the shear-band network becomes more penetrative and shear-bands thicker (from a few millimetres to centimetres) with a progressive development of ultramylonitic rocks to the top of the lower unit (Figs. 4d, 5a and 5b). Microstructural observations also reveal the eastward increase of deformation intensity. Indeed, weak to moderate solid-state microstructures (e.g. deformation lamellae, undulose extinction, chess-board subgrains of quartz) evolve to strong solid-state ones in mylonitic rocks (e.g. polycrystalline quartz aggregate formed by subgrain rotation recrystallization, dynamically recrystallized quartz; Fig. 4e) indicating crystal-plastic mechanisms (e.g. Gapais and Barbarin, 1986; Passchier and Trouw, 2005). A top-to-the SE 
sense of shear is unambiguously shown in thin-sections cut perpendicularly to foliation and parallel to stretching lineation, where observed structures are: biotite fish, oblique foliation, quartz and biotite pressure shadows, shear bands and $\sigma$ - or $\delta$-type porphyroclast systems with embayment for latter ones (Figs. 4e and 4f). Moreover, K-feldspar, plagioclase or quartz grains cut by fractures and microfaults are often observed, implying a superposed brittle deformation.

From this, to the east of the dome, considering the whole strain gradient, the total thickness of the N30-40E oriented strained zone can be estimated at $\sim 4 \mathrm{~km}$, including $\sim 0.5$ to $1.0 \mathrm{~km}$-thick of mylonitic to ultramylonitic rocks (Figs. 3a, 5a and 5b). This deformed zone separates two different units: (1) a lower unit composed of Linglong migmatitic and granitic rocks exhibiting a footwall of mylonitic to ultramylonitic rocks and (2) an upper unit made of weakly to undeformed Precambrian rocks (Jiaodong and Jingshan Group) that constitute the upper crustal hanging wall units. The eastern border of the Linglong dome can thus be defined as a master detachment fault with a top-to-the SE kinematic, separating high-grade metamorphic rocks pertaining to a lower unit from ante-metamorphosed rocks belonging to an upper unit. This master detachment is defined as the Linglong detachment fault (LDF; Figs. $3 a, 5 a$ and $5 b)$.

\subsubsection{Strain intensity modelling in the Linglong dome}

Based on field structural observations, a qualitative scale of ductile deformation intensity undergone by granitic and migmatitic rocks has been established. This scale of strain "amount" is graduated from a value equal to " 5 " for isotropic rocks to " 1 " for ultramylonites, with intermediate values corresponding to mineral preferred orientation appearance (" 4 "), well-developed foliation and stretching lineation (“3") and $\mathrm{S} / \mathrm{C}$ mylonites or foliation associated with shear bands structures ("2"). 
Geostatistics are more and more applied to Earth Sciences for spatial data analysis in order to characterize spatial pattern of variables and to predict values at non sampled locations, or map continuous variables from discrete measurements (e.g. Krige, 1951; Matheron, 1963; Davis, 1986; Isaaks and Srivastava, 1989). Using the strain "amount" value attributed at each visited outcrop, such a geostatistical approach has been applied to characterize the field measurements and, then, to interpolate a map of spatial distribution of ductile deformation intensity in the Linglong massif. As the Linglong migmatitic and granitic dome and the Guojialing pluton are two different geological objects, with probably two distinct internal strain fields, variogram analysis and ordinary kriging have been independently computed for each one (see $\$ 3.2 .3$ for the Guojialing pluton).

The results of semi-variogram analysis and corresponding ordinary kriging interpolation are presented in Table 1 and Figure 3b, respectively. Semi-variogram models reveal an anisotropic trend, i.e. preferential directions, for correlations between data point measurements. The direction of this major amplitude range is of N45E for the Linglong dome. A non-null value for the nugget effect $\left(\mathrm{C}_{0}=0.1123\right)$ denotes substantial deviations of the strain intensity value at local scale. This effect can be attributed to the lithological contrast in the dome, composed of granitic and migmatitic rocks. Figure $3 \mathrm{~b}$ shows the interpolated contoured mapping of ductile field strain intensity. As the isotropic reddish-pinkish Cretaceous granodioritic plutons intruded into the Linglong dome, these areas have not been taken into account for the computation. Within the Linglong dome, isotropic rocks of the core, i.e. low field strain intensity, contrast with the quite strong deformed zone of its southern and eastern edges (Fig. 3b). In particular, the map reveals high strain values along the eastern border of the dome (Fig. 3b) that corroborates the presence of the Linglong detachment fault (LDF). 


\subsection{The Guojialing massif}

3.2.1. The Guojialing pluton and the extensional Guojialing shear zone

The Guojialing massif is located in the Zhaoyuan-Sanshandao-Longkou area, north of the Linglong dome (Fig. 3a). Structural features of the Guojialing massif exposed below are illustrated by Figure 6. In contrast with the Linglong dome, no migmatitic rocks have been recognized and the lithology is very homogenous throughout the overall massif, showing simple pluton bulk architecture. This pluton presents the same granodioritic petrography as the discrete reddish-pinkish Cretaceous plutons intruded within the Linglong dome (see description above, §3.1.2) and intersects the Linglong detachment fault. Along its southern edge, where the Guojialing pluton intrudes the Linglong dome, the granodiorite is isotropic or presents a very weak preferred orientation underlined by biotite, $\mathrm{K}$-feldspar and/or amphibole (Fig. 6a). To the west, the occurrence of this typical lithological facies, still with an isotropic texture, has been observed up to Sanshandao city, which implies an extension of the Guojialing granodiorite below the Cenozoic sedimentary cover (Fig. 3a). Toward the northern border of the pluton, strain is marked by the progressive development of a north-westward dipping foliation underlined by biotite flakes, lineation is marked by quartz aggregates and amphibole crystals while C/S mylonitic structures progressively appear (Figs. $6 \mathrm{~b}$ and $6 \mathrm{c}$ ). At the vicinity to the northern contact with the country rocks, centimetre-scale shear bands of ultramylonites developed. To the whole, progressive decreasing in grain-size of the mylonites and $\mathrm{C} / \mathrm{S}$ angles clearly highlight the continuous shear increasing from $\mathrm{S}$ to $\mathrm{N}$ (Figs. 6b, 6c and 6e). Thick Cenozoic cover prevent from the observation of surrounding rocks close to the deformed zone, even though, in its close vicinity $(\sim 50-200 \mathrm{~m})$, rocks exhibit a continuous strain transition with the deformed granodiorite (Fig. 6e), as already been described as a "gneissic texture transitional to the country rocks" (SBGMR, 1991; Yang and Lü, 1996; Zhou and Lü, 2000). Stretching lineations measured in the pluton reveal a consistent N130-140E 
trend (Figs. 3a and 6e). Sigmoidal feldspars and C/S plane obliquities in the mylonitic rocks show a top-to-the NW simple shear (Figs. 6b and 6c). Thin section observations also reveal an increase of deformation intensity from $\mathrm{S}$ to $\mathrm{N}$. In fact, grains of quartz, plagioclase, Kfeldspar or biotite show distinct magmatic and weak solid-state to strong solid-state deformation microstructures. Crystal-plastic deformations are evidenced by elongated grains and grain aggregates, undulose extinction, deformation lamellae of quartz (Fig. 6d; Passchier and Trouw, 2005). A top-to-the NW shearing is clearly deduced from K-feldspar porphyroclast systems, biotite sigmoids, oblique foliation, biotite fish, amphibole domino boudins and asymmetric distribution of myrmekite (Passchier and Trouw, 2005; Simpson and Wintsch, 1989; Goscombe and Passchier, 2003).

The total thickness of the sheared zone attains up to $6 \mathrm{~km}$-thick, locally up to 1 to 2 km-thick of mylonitic rocks. In contrast with the Linglong dome, the Guojialing pluton is only composed of granodioritic rocks which have undergone progressive deformation as shown by decrease of C/S angles (Berthé et al., 1979; Figs. 6a to 6c and Fig. 6e). As a result, the Guojialing pluton may be considered as a synkinematic intrusion emplaced along a N80E striking ductile extensional shear zone, with a top-to-the NW sense of shear, defined as the Guojialing shear zone (GSZ; Figs. 3a and 6e).

\subsubsection{Strain intensity modelling in the Guojialing pluton}

The same qualitative ductile deformation intensity scale used in the Linglong massif has also been used for the Guojialing massif (\$3.1.4). The results of semi-variogram analysis and corresponding ordinary kriging interpolation are presented in Table 1 and Figure $3 \mathrm{~b}$, respectively. Semi-variogram models reveal as in the Linglong massif an anisotropic trend, i.e. preferential directions, for correlations between data point measurements. The direction of this major amplitude range is of N81E for the Guojialing pluton (Table 1), closely parallel to 
the elongated directions of the massif (Fig. 3a). The absence of nugget effect can be noted and reveals continuous gradients in strain intensity. In fact, the absence of nugget effect can easily be attributed to the rather single petrographic facies (i.e. only granodioritic rocks) in the Guojialing pluton. Figure 3b shows the interpolated contoured mapping of ductile strain intensity. The map reveals particularly high values along the northern border of the Guojialing pluton, corresponding to the Guojialing shear zone (GSZ; Fig. 3b). As a mean, the Guojialing pluton presents a significant strain intensity everywhere within the massif.

\section{Brittle deformation tectonics analysis in the Linglong and Guojialing massifs}

\subsection{Characterising the brittle features within the Linglong and Guojialing massifs}

The major structure remains the Linglong detachment fault (LDF). It displays clear evidence of late reworking under brittle conditions that can be followed over $\sim 20 \mathrm{~km}$ south of Zhaoyuan city (Figs. 3a and 4g). In the field, highly dipping thick breccia bodies (i.e. 10-50 m) overprint the ductile fabric (i.e. mylonites, ultramylonite bodies) characterizing the eastern Linglong dome border (Fig. 4h). Yellowish brecciated rocks composed of more or less decomposed granite and mylonite clasts are crossed by numerous milky or purplish quartz veins suggesting strong hydrothermal circulations. This assumption is illustrated by some gold mineralizations along the cartographic outline of the LDF (see gold mines symbols on Fig. 3a).

Second-order structures are characterized by N30E trending, up to $80 \mathrm{~km} \mathrm{long}$, localized brittle fault zones (e.g. Sanshandao or Xingcheng-Jiaojia faults; Fig 3a). Only few is known on these structures until now, mostly studied for mining exploration. They appeared either as high-angle fault-related hydrothermalized brecciated zones, cataclasites or localized mineralized quartz veins (i.e. stockworks) concentrating most of the Jiaodong gold deposits (Wang et al., 1998; Zhou and Lü, 2000; Li et al., 2003; Zhou et al., 2003; Mao et al., 2008). 
Yet, both Linglong and Guojialing massifs are penetratively affected by widespread small-scale faults and veins visible on outcrops. These structures, particularly abundant in granitic lithology, mainly display normal motion indicated by slickensides (Fig. 7d).

\subsection{Palaeostress field analysis}

Stress field responsible for the formation and the evolution of major brittle structures cannot be easily reached. A brittle microtectonic analysis allowed us to reconstruct changing palaeostress fields that have affected the Linglong and Guojialing massifs and to infer how the first-order structures were formed and then acted under reconstructed palaeostress fields.

\subsubsection{Methodology}

Palaeostress orientation patterns were evaluated by computer-aided inversion method for fault slip data which is described in details by Angelier (1979, 1984 and 1994) and the inversion method that has been used herein concerns T-TECTO 2.0 Professional software (see details in Žalohar and Vrabec, 2007). Output data consist in the determination of the reduced palaeostress tensor for a given data set, thus identifying the preferred orientation of the three principal stress axes $\left(\sigma_{1}, \sigma_{2}\right.$ and $\sigma_{3}$, the maximum, intermediate and minimum stress axis, respectively), and the ratio $\Phi=\left[\left(\sigma_{2}-\sigma_{3}\right) /\left(\sigma_{1}-\sigma_{3}\right)\right]$ reflecting the relative magnitude of principal stress axes. Reliability of computed palaeostress direction is estimated as a function of the "misfit angle" value (Žalohar and Vrabec, 2007; reflecting the Ratio UPsilon (i.e. RUP) of Angelier (1994)). Thus, the quality of computed principal stress axes is classed as following: $\mathrm{A}=$ well-defined $\left(0^{\circ} \geq\right.$ misfit angle $\left.>15^{\circ}\right), \mathrm{B}=$ quite well-defined $\left(15^{\circ}>\right.$ misfit angle $>25^{\circ}$ ) and $\mathrm{C}=$ poorly-defined (misfit angle $>25^{\circ}$ ).

The study was carried out in areas weakly affected by tectonism in order to avoid stress perturbation within and at the direct vicinity of major fault zone. Brittle tectonic 
analysis was realized using a representative number of striated fault planes exhibiting sense of slip indicators such as striae, Riedel subordinate planes, tensile cracks and more routinely from slickensides (i.e. quartz steps; see review in Doblas, 1998).

Most of the visited sites display evidence of polyphase faulting and are then characterized by an inhomogeneous character of the data sets. The fault sets, described in the "4.2.2. Results" section, have been grouped by their coherence. The main criteria for distinguishing the different fault sets considered are cross-cutting relationships and reactivation processes illustrated by superimposed and partially overprinted striae on the same fault plane. Striations are grouped to a specific fault population when their directions are coherent at $\pm 15^{\circ}$ with respect to the corresponding mean orientation deduced from statistics (i.e. rose diagram).

\subsubsection{Results}

A total of 911 fault planes have been selected from the 1176 measured fault planes in the field issued from 39 microtectonic sites. Selection of the computed fault data relies on incompatible striation directions with a specific fault population and field measurement errors (i.e. poorly marked slickensides). Results of the microtectonic study carried out in the Linglong and Guojialing massifs are presented in Table 2 and Figure 7. For all sites, it is noteworthy that maximum and minimum stress axes (i.e. $\sigma_{1}$ and $\sigma_{3}$ ) are subvertical and subhorizontal, respectively (Fig. 7a) which is typical of normal faulting. Palaeostress analysis reveals two main orthogonal stress regimes. For the dominant stress regime, visible on all of the 39 sites, minimum stress axis $\sigma_{3}$ direction trends N118E and is linked to a NW-SE extensional event. This stress field is constrained by $87 \%$ of A-B quality estimator (Table 2 and Fig. 7b) even for low-measurement sites (e.g. sites 131 and 169). N118E averaged stress field appears highly coherent in the whole Linglong and Guojialing massifs whatever the 
position in the massifs and/or lithology encountered. No spatial fracturing gradient (i.e. fault occurrence/displacement) can be evidenced, however, fault occurrence are rather well distributed over the Linglong and Guojialing massifs and form a homogeneous penetrative network. In contrast, a subordinate stress regime yields a N33E minimum stress axis direction (linked to a NNE-SSW extensional event) for 14 sites (Fig. 7 and Table 2, in italic font). Reliability for this stress determination is rather low, only about $29 \%$ of $\sigma_{3}$ directions are in quality A-B (i.e. sites 77' and 110'; Table 2 and Fig. 7b).

Although the tectonic significance for the NNE-SSW ( N30E) oriented extensional stress regime remains unclear, the dominant NW-SE extensional event appears in good accordance with the mean ductile stretching lineation direction (i.e. N120E; Figs. 3a and 7b). Links between the ductile and brittle deformations in the Linglong and Guojialing massifs during the Mesozoic geodynamic event will be discussed below.

\section{Deep architecture of the Linglong and Guojialing massifs using gravity data} modelling

Gravity data analysis and modelling have already proven their efficiency for imaging geological structures to depth (e.g. Bott and Smithson, 1967; Ajakaiye and Sweeney, 1974; Vigneresse, 1983; Vigneresse and Brun, 1983; Martelet, 1999; Martelet et al., 2004; Talbot et al., 2004; Joly et al., 2009). In this study, new and available gravity data have been used to model the bulk crustal-scale architecture of the Linglong and Guojialing massifs and, more precisely, the geometrical relationships between them.

\subsection{Gravity map interpretation}

At the first-order, the Bouguer anomaly map of the study area depicts the heterogeneous distribution of masses at depth and is well consistent with geological 
boundaries (Fig. 8a; Ma, 1997). Highest Bouguer anomalies correspond to rather dense Precambrian basement rocks whereas granitic rocks of the Linglong dome and Guojialing pluton can be well correlated with lower anomalies (compare contours and geological boundaries on Fig. 8a). If comparing both massifs, the higher negative anomalies are localized in the Linglong dome, which is consistent with either lighter rocks or thicker low-density units, with respect to the Guojialing pluton. On both eastern and western sides of the Linglong dome, isocontours of Bouguer anomaly strike parallel to the geological boundaries and display particularly strong gradients at the contact with the country rocks (Fig. 8a). Conversely, to the south of the dome, isocontours bend and cross-cut the geological boundaries. The corresponding negative Bouguer anomaly can be tracked up to $10 \mathrm{~km}$ south of the edge of the dome and gradients are clearly lower southwardly (Fig. 8a). Due to lower density contrasts with its enclosing rocks, and in particular with the Linglong dome, the nature of the Guojialing pluton boundaries can be hardly deduced to depth from the Bouguer anomaly map. Nevertheless, combined with geological observations at surface (see §3), the western boundary of the Guojialing pluton might thus be drawn further west up to the cape and close to the Sanshandao city (Figs. 3a, $7 \mathrm{~b}$ and $8 \mathrm{a}$ ).

\subsection{Gravity profiles}

\subsubsection{Acquisition and treatment of data}

In order to enrich the gravity database and particularly to image more precisely the geometry of contacts between granitic and migmatitic rocks and its country rocks, gravity measurements have been carried out along two cross-sections, perpendicularly to the Linglong dome long axis (Figs. 3a and 8a). The first cross-section lies between Laizhou and Guojiadian cities ( $70 \mathrm{~km}$ long with 85 stations; Fig. 8b), and the second one between Sanshandao and Zhaoyuan cities ( $\sim 67 \mathrm{~km}$ long with 81 stations; Fig. $8 \mathrm{c})$. Stations are spaced 
$1 \mathrm{~km}$ apart, and $500 \mathrm{~m}$ for the segments crossing the contact between the Linglong dome and its country rocks. Precise geographic coordinates (Longitude/Latitude) and altitude for each station were measured using a MAGELLAN d-GPS system that ensures a centimetre-scale precision. All gravity measurements were achieved using a SCINTREX CG5-M microgravimeter. The gravity anomaly was computed with respect to the theoretical value of $g$ on GRS-1967 ellipsoid. To obtain the Bouguer anomaly, we successively performed standard free air, plateau and terrain corrections. Terrain corrections have been computed up to $167 \mathrm{~km}$ according to Martelet (1999). A $2.67 \mathrm{~g} . \mathrm{cm}^{-3}$ Bouguer reduction density has been chosen as the mean density for the studied granitic rocks. The Moho depth of the study area, deduced from tomographic data, has been extracted from Hao et al. (2007).

\subsubsection{Gravity profile modelling}

Two dimensional (2D) gravity modelling has been performed using the Geosoft-GMSYS software along the two gravity profiles (Figs. 8b and 8c). Direct modelling consists in adjusting densities of the considered geological units with their geometry. For this study, average densities were derived from literature and laboratory measurements (Wan et al., 2001; see Fig. 8 for more details) and 2D geometries were highly constrained by available geological maps and our own field observations as well as measurements.

The southern profile runs perpendicularly to the long axis of the Linglong dome from Laizhou through Guojiadian cities toward to the ESE (Fig. 8b). This profile cuts across the dome in its central part. Figure $8 \mathrm{~b}$ presents the modelling results showing a rather simple crustal-scale structure with a good fit between measured and modelled anomaly values. The central part of the profile, marked by a well-defined low gravity anomaly, corresponds to a dome-shaped composed of granites, migmatites and certain upward of middle to lower crustal rocks. Even if imbrications of migmatites with granitic rocks have been observed in the field, 
at the scale of this model section, granitic rocks s.s. appear as a laccolite shape of about 2 to 5 $\mathrm{km}$ thick on top of the migmatitic rocks (Fig. 8b). High gravity anomalies located to the west and to the east of the profile correspond to the Archaean and upper crustal rocks surrounding the Linglong dome. On the eastern border of the Linglong dome, the LDF (§3.1) displays a moderate eastward dipping and connects with a flat interface at about $10 \mathrm{~km}$ depth (Fig. 8b). Along the western boundary, the contact dips to the west with a slightly higher angle. The Moho discontinuity exhibits a flat-lying geometry.

The northern profile (Fig. 8c) also runs perpendicularly to the long axis of the Linglong dome and cross-cuts its boundary with the Guojialing pluton. At the first-order, the computed model is in good accordance with the measured gravity anomalies. In the northern part of the study area, the model reveals a rather more complicated structure showing the geometrical outline of the Linglong and Guojialing massifs. Compiling with structures shown on the southern profile, the eastern part of this profile model displays a dome-like shape: (1) granitic rocks of the Linglong dome presents a laccolite of $\sim 3$ to $6 \mathrm{~km}$ thick on top of the migmatites and (2) the LDF displays as a moderate eastward dipping contact that becomes flat at depth (Fig. 8c). To the west of the profile, a weaker negative Bouguer anomaly is due to the Guojialing pluton which draws a thin laccolite (of maximum $3 \mathrm{~km}$ thick) over upper crust units. The modelled geometry of the Guojialing laccolite shows a root along its boundary with the Linglong massif, which clearly shows its intrusive relation with the dome (Fig. 8c). At the second order, pinkish-reddish Cretaceous granodiorites can be added to the model as late intrusions within the Linglong dome (Figs. 3a and 8b). In addition, the Luanjiahe pluton is intruded into the Archaean and upper crustal surrounding rocks to the east of the LDF (Figs. 3a and 8c). Still again, the Moho discontinuity is flat under this northern modelled profile. 


\section{Discussion}

6.1. Finite 3D geometry of the Linglong MCC and of the Guojialing synkinematic pluton

Figures $9 \mathrm{a}, 9 \mathrm{~b}$ and $9 \mathrm{c}$ present block diagrams of the crustal-scale structure drawn for the entire Linglong and Guojialing massifs and designed from a 3D computed model using the 3D GeoModeller software (CIntrepid-BRGM; and see Lajaunie et al., 1997 and Calcagno et al., 2002 for methodology). In this study, modelling integrates all the field structural observations and geophysical measurements (i.e. gravity profiles) to constrain a consistent best fitting geometry. Four main units have been distinguished in this 3D model: (1) the Linglong dome; (2) the Guojialing pluton; (3) pinkish-reddish isotropic plutons intruded into the Linglong dome; and (4) the country units (Figs. 9a, 9b and 9c). Despite apparent resemblances in terms of overall structures and kinematics, the Linglong dome and the Guojialing pluton must be distinguished, as discussed below.

Field observations shows that the Linglong massif is composed of intensively imbricated migmatitic and granitic rocks. Gravity analysis and modelling highlight the domeshaped of this massif with a particularly deep rooting of the migmatitic rocks and granites in the middle crust (Figs. 8b, 8c and 9c). In details, these gravity models show that the granite seems to roof the migmatites and it is noteworthy that this lithologic arrangement is similar to the geometry described for the Shushwap MCC (Vanderhaeghe, 1999). Gravity profiles (Figs. $8 \mathrm{~b}$ and $8 \mathrm{c}$ ) have shown horizontal upper/middle crust interface as well as a flat-lying Moho geometry, with a normal current crustal thickness (i.e. $~ 30 \mathrm{~km}$, Hao et al., 2007). Ductile deformation analysis of the Linglong dome highlights a master detachment fault (LDF), with a top-to-the SE sense of shear, which separates a lower unit, made of migmatitic and granitic rocks (in the core of the dome), from an upper unit made of ante-metamorphosed Precambrian rocks to the east (Figs. 3a, 5a and 5b). The N30E trend of the LDF is structurally compatible 
with stretching lineations revealing a consistent N120-140E strike within the entire dome (Fig. 3a). Geostatistical modelling of the field strain intensity has put forward a N45E preferential direction for correlation among data values. This direction is closely parallel to the trend of the LDF (Fig. 3b) showing the consistency between the detachment orientation and the finite strain field within the entire dome. Moreover, the structural analysis and strain intensity modelling show a systematic increase of the deformation as well as a straightening up of the foliation planes, from $\mathrm{W}$ to $\mathrm{E}$, i.e. from core to border (Figs. 3b, 5a and 5b). From these two latter observations, one can infer that the internal ductile deformation within the lower unit (i.e. Linglong dome) is contemporaneous with the strain localization along the LDF. Upper unit (Early Proterozoic and Late Archaean) exhibit an old ductile fabric inherited from Palaeoproterozoic orogens (An, 1990; Lü and Kong, 1993; Zhang et al., 1994) and cannot be related to LDF. Referring to previous works (Makris, 1978; Davis and Coney, 1979; Crittenden et al., 1980; Allmendinger et al., 1987; Hauser et al., 1987; Lister and Davis, 1989; Malavieille, 1993), results from this study allow us to interpret the Linglong dome as a Metamorphic Core Complex, an asymmetric one in that case as only one ductile detachment (LDF) developed along its eastern flank (Fig. 9a). Thus, the Linglong MCC is composed of (1) a lower unit made of high-grade metamorphic rocks (migmatites) and granitic ones, (2) an upper unit made of previously metamorphosed upper crustal rocks (Early Proterozoic and Late Archaean), and a master detachment zone separating the two latter units (the LDF zone).

The southern edge area of the Linglong MCC presents a peculiar strain field with respect to the rest of the dome. Firstly, the foliation plane orientations vary parallel to the dome outline through its terminations while the stretching lineation is consistently striking N120-130E all over the dome (Fig. 3a). Secondly, gravity data show that the dome extends to the south with a shallow depth below the upper unit rocks (Fig. 8a). Thirdly, Kriging interpolation of the field strain intensity shows that this part of the MCC is more deformed 
than its core and further western area from the LDF (Fig. 3b). This southern area can thus be regarded as a more deformed external layer of the footwall lower unit rocks, gently dipping to the south and parallel to the external boundary of the dome. In that frame, the central part of the Linglong massif would correspond to a deeper erosion level and display the more internal, only weakly deformed part of the MCC (referring Figs. 9a, 9b and 9c). Yet, the southern "termination" of the MCC, as figured on the maps, does thus not correspond to the "real" end of the dome. This implies that: (1) the LDF must extend to the south, along a $\sim \mathrm{N} 30 \mathrm{E}$ strike (Figs. 8a and 8c) and (2) the apparent throw progressively decreases toward to south, leaving the upper crust units in contact on both sides of the detachment fault zone (Fig. 9d).

As deduced from the gravity modelling (Fig. 8c), the rather thin laccolitic shape of the Guojialing pluton highly contrasts with the deep rooting of the huge Linglong MCC (Fig. 9b). In addition, this pluton is only composed of deformed granodioritic rocks (absence of migmatites) and is bounded to the northwest by a ductile extensional intracrustal shear zone characterized by a top-to-the NW sense of shear (GSZ; Fig. 9b). The whole pluton is pervasively affected by progressive sub-solidus deformation and C/S typical fabric moving toward the GSZ. C/S angles decrease from south to north of the pluton (Figs. $6 b, 6 c$ and $6 e$ ). $\mathrm{C} / \mathrm{S}$ fabrics in granitic rocks are diagnostic of a synkinematic emplacement of pluton as described by Berthé et al. (1979). The emplacement of the Guojialing granodiorite can thus be considered as synkinematic.

The western edge of the Guojialing synkinematic pluton is sometimes localized along the NNE-SSW striking Xingcheng-Jiaojia structure defined either as a fault zone or a ductile shear zone (Fig. 3a; e.g. Wan et al., 2001; Lu et al., 2007). However, field observations and the gravity data analysis realized from this study show that the Guojialing synkinematic pluton can be extended further west, at least up to the cape, south of the town of Sanshandao (Figs. 3a and 8a). Besides, geostatistical modelling of the field strain intensity values revealed 
a well-constrained N81E "range" anisotropic direction - correlation preferred direction between data values - parallel to the mean GSZ strike, as defined in this study (Fig. 3b and Table 1). On the resulting interpolated contour map, highest strain intensities of the massif are localized along a ENE-E striking band underlining that high shear strain is only localized along the northern boundary of the pluton instead of its western edge (i.e. along the Xingcheng-Jiaojia structure; Figs. $3 a$ and $3 b$ ). From all these features, it is reasonable to assume that the synkinematic Guojialing pluton emplacement is controlled by one single intracrustal shear zone, the GSZ, localized to the north.

\subsection{MCC vs. synkinematic pluton: significance in term of amount of crustal extension}

The Linglong and Guojialing massifs encompass in Metamorphic Core Complex and synkinematic pluton, respectively, which implies drastically different consequences in terms of amount of crustal-scale extension. The purpose of this part is to review what the significance of the terms "MCC" or "synkinematic pluton" commonly used in this context to ensure correct implications to the studied case.

The term "metamorphic core complex" (MCC) has been firstly defined in the Basin and Range Province (Davis and Coney, 1979; Crittenden et al., 1980; Wernicke, 1981; Lister and Davis, 1989), and then recognized in the Aegean area (Lister et al., 1984; Gautier et al., 1990; Sokoutis et al., 1993; Jolivet et al., 2001), and in other places (syntheses in Dewey, 1988; Whitney et al., 2004). MCC are traditionally divided into two units: (1) a lower unit composed of high-grade metamorphic and migmatitic rocks, and/or plutonic bodies associated with, (2) an upper unit consisting in upper crust, non-metamorphosed or previously metamorphosed rocks associated with syntectonic basin infill. Both units are separated by a master detachment fault zone comprising mylonitic to ultramylonitic rocks, developed to depth and exhumed in the footwall of this extensional shear zone, and overprinted brittle 
fabrics developed within upper crust, during exhumation. MCC development results from a strong tectonic denudation, in a continental lithospheric extension setting, responsible for the exhumation and deformation of middle to lower crustal rocks. This structure reveals a high extensive strain undergone by the crust and leads to consider a large amount of extension (Fig. 9e). According to analogue and numerical modelling of MCC development (e.g. Brun et al., 1994; Rey et al., 2009), the minimum amount of extension may correspond to the total width of the outcropping lower unit rocks (Fig. 9e); this represents a minimum of $\sim 30 \mathrm{~km}$ in the case of the Linglong MCC.

Magmatism is often evoked as an important factor for extension process, favouring crustal partial melting that strongly weakens the lithosphere emphasizing deformation and strain localization (Davis and Coney, 1979; Reynolds and Rehrig, 1980; Coney and Harms, 1984; Lister et al., 1984; Lynch and Morgan, 1987). Indeed, as a result of synextensional magmatism, granitoids often emplaced into upper continental crust. It is long time known that granitoids are efficient marker to study crustal deformation (e.g. Cloos, 1925; Balk, 1937; Brun and Pons, 1981; Gapais and Barbarin, 1986; Hibbard, 1987; Paterson et al., 1989; Ramsay, 1989; Faure and Pons, 1991; Paterson et al., 1998). Continental areas affected by extension often exhibit sheared or synkinematic plutons emplaced along major shear zones accommodating lithosphere extension (e.g. Faure and Pons, 1991). The ambiguous term of "sheared pluton" can correspond to: (1) the deformation of pre-tectonic plutons by ductile shear zones or (2) the "synkinematic" or "syntectonic" emplacement of a pluton here deformed in subsolidus conditions. Granitoids can also emplace in a post-tectonic setting; they do not undergo regional-scale related deformation and are sub-isotropic in that case.

The essential point arising out of the preceding discussion is that MCC requires much stronger crustal extension than pluton -sheared or not- in a way to drive upward of lower to middle crustal rocks (Fig. 9e). Besides, extensional setting is not necessary to allow pluton 
emplacement as shown for examples in Variscan Belt (e.g. Berthé et al., 1979; RománBerdiel et al., 1998). It is thus crucial to well characterize and differentiate those both geological objects so as to better interpret crustal-scale extension, which is especially true for eastern China.

\subsection{Timing and tectonic history}

This study brings new field structural observations that allow defining precisely the kinematics of the Linglong MCC and Guojialing synkinematic pluton as well as the overall field stress during late brittle deformation. Based on a critical compilation of available geochronological data (Fig. 2), the tectonic evolution of the Linglong and Guojialing massifs can be drawn by three main stages during extension. Yet, these successive steps (i.e. 150 to $130 \mathrm{Ma}, 130-124 \mathrm{Ma}$ and 120-100 Ma) are presented on Figure 9.

Firstly, the partial melting in the Linglong MCC has been constrained by $\mathrm{U} / \mathrm{Pb}$ ages on zircon issued from granitic rocks interlayered into migmatites around 160-150 Ma (Miao et al., 1998; Wang et al., 1998; Luo et al., 1999). The granitic and migmatitic rocks of the Linglong MCC exhumed below a master east-dipping detachment fault (i.e. LDF in the text) that could be tracked, along-strike to the south, within its surrounding rocks (Fig. 9a). The consistent N120-140E stretching direction deduced from the structural analysis shows that this MCC exhumed in a NW-SE striking extensional context, consistent with the structural axes of the Mesozoic pervasive continental extension in eastern China (e.g. Davis et al., 1996; Ren et al., 2002; Ratschbacher et al., 2003; Darby et al., 2004; Liu et al., 2005; Lin and Wang, 2006). The lack of geochronological data does not permit to precisely determine the age of the deformation along the LDF but, given that the MCC is intersected by the synkinematic Guojialing pluton, its exhumation and cooling must occur prior to this intrusion, as detailed below. It should be noted here that coarse-clastic continental sediments might have been 
deposited along the normal faults system associated with the LDF but such relationships have never been described in the area.

During a second stage, the synkinematic Guojialing pluton thus intruded into the Linglong MCC as observed in the field and as deduced from gravity models; on map view the Guojialing pluton clearly intersects the Linglong detachment fault (LDF). Emplacement (U/Pb ages on zircon, 130-126 Ma; Guan et al., 1998; Wang et al., 1998) and subsequent cooling $\left({ }^{40} \mathrm{Ar} /{ }^{39} \mathrm{Ar}\right.$ ages on biotite, $124 \mathrm{Ma}$; Li et al., 2003) of the synkinematic granodiorite pluton are both dated at Early Cretaceous times that also corresponds to the age of this deformation stage. These points argue that (1) in spite of the lack of geochronological data on footwall mylonitic rocks in the LDF zone, the exhumation of the Linglong MCC must have exhumed and cooled between 150 and $130 \mathrm{Ma}$ (Late Jurassic to Early Cretaceous), and (2) the LDF and the GSZ cannot be coeval nor be considered as conjugate shear zones. The N130140E stretching direction measured within the Guojialing pluton is not strictly perpendicular to the GSZ, but, here again, is consistent with the regional NE-SW striking regional extension reported for the whole eastern China (e.g. Ren et al., 2002; Lin and Wang, 2006).

Finally, the Linglong MCC and Guojialing synkinematic pluton, and probably the entire region were affected by a dense brittle faulting that offsets and sometimes reworks ductile extensional features (Fig. 9c). Microtectonic study carried out in the area revealed a mean N120E trend for minimum stress axis $\left(\sigma_{3}\right)$, parallel to the bulk N120-140E ductile stretching direction characterizing the Linglong MCC and Guojialing synkinematic pluton. As shown by the spatial distribution of gold mines (Figs. 3a and 9c), mineralizations are closely linked to brittle tectonics as ore deposits concentrated in cataclasites and associated faults (i.e. Xingcheng-Jiaojia Fault). Intensive dating of mineralizations associated with fluid circulations yields a well-constrained 120 Ma age (Li et al., 2003; Zhang et al., 2003), which confirms the succession of the brittle deformation with the two former stages of ductile strain 
during Linglong MCC exhumation and later Guojialing pluton intrusion. This last stage is followed by the intrusion of late reddish-pinkish granodioritic plutons exhibiting clear posttectonic isotropic textures (Figs. 2 and 9c).

At larger scale, this study of the Jiaodong Peninsula argues for the existence of the continental extension event, in eastern China, with a stable NE-SW stretching direction from ductile to brittle conditions, at least from the Early Cretaceous (130 Ma). Moreover, this study brings new insights implying a possible extensive setting prior to $130 \mathrm{Ma}$ as exposed below.

Previous studies have shown that, in eastern China, MCC and plutons mainly emplaced between 130 and $110 \mathrm{Ma}$ (i.e. $\mathrm{U} / \mathrm{Pb}$ on zircons and ${ }^{40} \mathrm{Ar} /{ }^{39} \mathrm{Ar}$ on synkinematic minerals; Davis et al., 1996; Webb et al., 1999; Wu et al., 2005b, 2007; Lin et al., 2008) leading some authors to consider that period as a climax of extension rate (cf. Wu et al., 2005a). In the present study, the emplacement and cooling ages of the Guojialing synkinematic pluton (130-124 Ma) demonstrates that extension is well active during that time in the Jiaodong Peninsula. However, it has also been shown that the Linglong MCC has been exhumed below a master detachment fault (i.e. the LDF) during Late Jurassic to Early Cretaceous times. Considering that the formation of a MCC reveals high amounts of strain ( 6.2 and Fig. 9e), an intense regional-scale extension must have occurred at the same time in Jiaodong Peninsula. The Late Jurassic-Early Cretaceous interval is a key period for tectonic setting inversion in eastern China (i.e. from compressive to extensive) as shown by controversy on Tan-Lu fault timing (e.g. Uchimara et al., 1996; Lin et al., 2003; Zhu et al., 2005) or tectonic setting in Yanshan belt (e.g. Dong et al., 1998; Zhang et al., 1998; Davis et al., 2009; Hu et al., 2009). It is noteworthy that Late Jurassic-Early Cretaceous age for extension has recently been described in Mongolia for MCC (e.g. Ereendavaa Range; Daoudene et al., 2009). In Liaoning Province, the Songliao basin exhibits Late Jurassic sediments (J3: 160-145 Ma) deposited during an extensive setting for this period (Chen et al. 
1999; Lin et al., 2003). In the same area, Lin et al. (2008) proposed that an extensive setting could occur during Late Jurassic to Early Cretaceous in the South Liaonan MCC. As exposed above, the rather old exhumation age of the Linglong MCC shows that, locally, the maximum extension rate can be reached quite earlier during the continental extension event and that, even to the east, the deformation climax cannot be restricted to the only Cretaceous period.

\subsection{Geodynamic implications for the extensional event}

During Mesozoic times, drastic changes in tectonic regime occurred in eastern Asia. Whereas the Late Permian-Early Triassic period is characterized by nappe-stacking and HP rocks burial (e.g. UHP eclogites; Okay et al., 1993; Hu et al., 1995; Ratschbacher et al., 2003), the Cretaceous witnesses, in contrast, a large-scale extensional event (e.g. Zhao et al., 1994; Ratschbacher et al., 2003; Zhai et al., 2007). This study reveals that typical extensional crustal-scale structures developed through the Jiaodong Peninsula, i.e. the Linglong MCC and

the Guojialing synkinematic pluton, from Late Jurassic to Early Cretaceous. NW-SE extensional kinematics deduced from our structural study are in good agreement with similar structures already recognized over eastern Asia. They may be summarized as follows: (1) Late Mesozoic synkinematic plutons with magmatically oriented core and mylonitic rim associated with the coeval development of ductile extensional shear zones (Lin et al., 2007), and (2) several MCC, such as the Yunmengshan in north of Beijing (Davis et al., 1996), the Yiwulüshan and the South Liaodong in Liaoning Province (Darby et al., 2004; Liu et al., 2005; respectively), and as far as the Ereendavaa Range in eastern Mongolia (Daoudene et al., 2009).

Geodynamic cause(s) for the Mesozoic extensional event in eastern Asia is still highly disputed. One of the following models may be invoked: models of back-arc extension inferred from subduction of a Palaeo-Pacific plate, thermomechanical convective ablation of the 
lithosphere, post-orogenic collapse or mantle plume effects are proposed to explain this tectonic event (e.g. Ren et al., 2002; Meng, 2003; Lin and Wang, 2006). Models for continental extension, as previously proposed (e.g. Buck, 1991; Corti et al., 2003) are hardly applicable to the peculiar area of eastern Asia, revealing a very unusual behaviour of the crust or entire lithosphere. As the study area is still limited, detailed discussion on these models is beyond the scope of this paper and requires further investigations.

\section{Conclusions}

From a rather accurate structural analysis of the western Jiaodong Peninsula, this study brings new constraints on the modes of deformation of the crust during the Mesozoic continental extensional event that took place in eastern China. Main conclusions can be drawn as follows:

1. The Linglong granitic and migmatitic dome is an asymmetric Metamorphic Core Complex, bounded by the Linglong detachment fault (LDF), probably exhumed during Late Jurassic to Early Cretaceous times and associated with a strong NE-SW horizontal crustal extension;

2. The Guojialing granodioritic pluton is a synkinematic pluton emplaced and cooled during Early Cretaceous (130-124 Ma) intersecting the Linglong MCC and the Linglong detachment fault into a NE-SW extensional setting;

3. Strain axes orientations remain particularly stable during the whole of the Mesozoic extensional setting in the Jiaodong Peninsula, with a homoaxial NE-SW extension deduced either from ductile and brittle structural analyses;

4. The maximum amount of extension in Jiaodong Peninsula is marked by the Linglong MCC exhumation and may occur between 150 and 130 Ma. Nevertheless, more 
geochronological data are required to better constrain the timing of exhumation of the Linglong MCC, using, for instance, ${ }^{40} \mathrm{Ar}-{ }^{39} \mathrm{Ar}$ datings on mylonitic footwall rocks of LDF.

\section{Acknowledgements}

This study benefited from a grant in the frame of the French national "Failles-FluidesFlux" project supported by the INSU-CNRS. The field work was financed by the Chinese National 973 Project $n^{\circ} 2009$ CB825008. The first author also benefited a scholarship grant from the French Minister of Education and Research. We present our thanks to Mr. K. CHEN (IGGCAS-Université d'Orléans) and Mr. J. WANG (IGGCAS) for their supports on the field during gravity measurements. Dr. G. MARTELET (BRGM: French Geological Survey) is also greatly thanked for his technical support for treatment of gravity data. Dr. F. CAGNARD is also acknowledged for constructive remarks on the manuscript. We thank Pr. G. DAVIS and an anonymous reviewer for their useful and constructive comments to improve our manuscript.

\section{References}

Ajakaiye, D.E., Sweeney, J.F., 1974. Three-dimensional gravity interpretation of the Dutsenwai complex, Nigerian younger granite province. Tectonophysics 24, 331-341.

Allmendinger, R.W., Nelson, K.D., Potter, C.J., Barazangi, M., Brown, L.D., Oliver, J.E., 1987. Deep seismic reflection characteristics of the continental crust. Geology 15, 304-310.

An, Y.H., 1990. Division of metamorphic stratigraphy in Jiaodong region: introducing Jiaodong and Jingshan Groups. Geology of Shandong Province 6, 97-102 (in Chinese). 
Angelier, J., 1979. Determination of the mean principal directions of stress for a given fault population. Tectonophysics 56, 17-26.

Angelier, J., 1984. Tectonic analysis of fault slip data sets. Journal of Geophysical Research $89,5835-5848$.

Angelier, J., 1994. Paleostress determinations. In: Hancock, P.L. (Ed), Continental deformations. Pergamon Press, Tarrytown, N.Y., 53-100.

Allen, M.B., McDonald, D.I.M., Xun, Z., Vincent, S.J., Brouet-Menzies, C., 1998. Transtensional deformation in the evolution of the Bohai Basin, northern China. In: Holdsworth, R.E., Strachan, R.A., Dewey, J.F. (eds), Continental transpressional and transtensional tectonics. Geological Society, London, Special Publications 135, 215-229.

Balk, R., 1937. Structural behaviour of igneous rocks. Geological Society of America Memoir 5, pp.177.

Berthé, D., Choukroune, P., Jegouzo, P., 1979. Orthogneiss mylonite and non coaxial deformation of granites: the example of the South Armorican Shear Zone. Journal of Structural Geology 1, 31-42.

Bott, M.H.P., Smithson, S.B., 1967. Gravity investigations of subsurface shape and mass distributions of granite batholith. Bulletin of Geological Society of America 78, 859-878. 
Brun, J.P., Pons, J., 1981. Strain patterns of pluton emplacement in a crust undergoing noncoaxial deformation. Journal of Structural Geology 3, 21-229.

Brun, J.P., Sokoutis, D., Van Den Driessche, J., 1994. Analogue modeling of detachment fault systems and core complexes. Geology 22, 319-322.

Buck, W.R., 1991. Modes of continental lithospheric extension. Journal of Geophysical Research 96(B12), 161-178. doi:10.1029/91JB01485.

Calcagno, P., Martelet, G., Gumiaux, C., 2002. Apport de la modélisation géométrique 3D à l'interprétation géologique du complexe de Champtoceaux (Massif Armoricain). Réunion des Sciences de la Terre 79, Nantes.

Chen, Y., Zhu, Y., 1993. Mineral deposit models of China. Geological Publishing House, Beijing, 367p. (in Chinese).

Chen, J., Cai X., Lin, C., Wang, H., Lei, M., 1999. Tectonic characteristics and episodic evolution of the northern fault depression in Songliao Basin. Acta Petrologica Sinica 20, 1418 (in Chinese with English abstract).

Cloos, H., 1925. Einfurhrung in die tectonische Behandlung magmatischer Erscheinungen: pt 1: Das Riesengebirge in Shlesien. Gebr., Borntraeger, Berlin, 194 (quoted in R. Balk, 1937).

Coney, P.J., Harms, T.A., 1984. Cordilleran metamorphic core complexes: Cenozoic extensional relics of Mesozoic compression. Geology 12, 550-554. 
Corti, G., Bonini, M., Conticelli, S., Innocenti, F., Manetti, P., Sokoutis, D., 2003. Analogue modelling of continental extension: a review focused on the relations between the patterns of deformation and the presence of magma. Earth Science Reviews 63, 169-247.

Crittenden, M.D., Coney, P.J., Davis, G.H., 1980. Tectonic significance of metamorphic core complexes of the North American Cordillera. Memories of Geological Society of America, 153.

Daoudene, Y., Gapais, D., Ledru, P., Cocherie, A., Hocquet, S., Donskaya, T.V., 2009. The Ereendavaa Range (north-eastern Mongolia): an additional argument for Mesozoic extension throughout eastern Asia. International of Earth Sciences (Geol Rundsch). doi: $10.1007 / \mathrm{s} 00531-008-0412-2$.

Darby, B.J., Davis, G.A., Zhang, X., Wu, F., Wilde, S., Yang, J., 2004. The newly discovered Waziyu metamorphic core complex, Yiwulüshan, western Liaoning province, Northwest China. Earth Science Frontiers 11, 145-155.

Davis, G.H., Coney, P.J., 1979. Geologic development of the Cordilleran metamorphic core complexes. Geology 7, 120-124.

Davis, J.C., 1986. Statistics and data analysis in geology. $2^{\text {nd }}$ edition, John Wiley \& Sons, New York, 289p. 
Davis, G.A., Qian, X., Zheng, Y., Yu, H., Wang, C., Mao, T.H., Gehrels, G.E., Muhammad S., Fryxell, J.E., 1996. Mesozoic deformation and plutonism in the Yunmeng Shan: A Chinese metamorphic core complex north of Beijing, China. In: A. Yin \& T.A. Harrison, Eds., The tectonic evolution of Asia. Cambridge University Press, New York, 253-280.

Dewey, J.F., 1988. Extensional collapse of orogens. Tectonics 7, 1123-1139.

Doblas, M., 1998. Slickenside kinematic indicators. Tectonophysics 295, 187-197.

Dong, S.W., Zhang, Y.Q., Long, C.X., 2008. Jurassic tectonic revolution in China and new interpretation of the "Yanshan Movement". Acta Geologica Sinica 82, 334-347.

Fan, W.M., Guo, F., Wang, Y.J., Lin, G., Zhang, M., 2001. Post-orogenic bimodal volcanism along the Sulu orogenic belt in eastern China. Physical and Chemical Earth 26, 733-746.

Fan, H.R., Hu, F.F., Yang, J.H., Zhai, M.G., 2007. Fluid evolution and large-scale gold metallogeny during Mesozoic transition in the Jiaodong Peninsula, eastern China. In: Zhai, M.-G., Windley, B.F., Kusky, T.M. \& Meng, Q.R. (eds), 2007. Mesozoic sub-continental lithospheric thinning under eastern Asia. Geological Society, London, Special Publications 280, 303-316.

Faure, M., Pons, J., 1991. Crustal thinning recorded by the shape of the NamurianWestphalian leucogranite in the Variscan belt of the northwest Massif Central, France. Geology 19, 730-733. 
Faure, M., Sun, Y., Shu, L., Monié, P., Charvet, J., 1996. Extensional tectonics within subduction-type orogen. The case study of the Wugongshan dome (Jiangxi Province, SE China). Tectonophysics 263, 77-108.

Gapais, D., Barbarin, B., 1986. Quartz fabric transition in a cooling syntectonic granite (Hermitage Massif, France). Tectonophysics 125, 357-370.

Gautier, P., Ballèvre, M., Brun, J.P., Jolivet, L., 1990. Extension ductile et bassins sédimentaires mio-pliocènes dans les Cyclades (îles de Naxos et Paros). Comptes-Rendus de l'Académie des Sciences de Paris 310, 147-153.

Goscombe, B., Passchier, C.W., 2003. Asymmetric boudins as shear sense indicators - an assessment from field data. Journal of Structural Geology 25, 575-589.

Guan, K., Luo, Z., Miao, L., Huang, J., 1998. SHRIMP in zircon chronology for Guojialing suite granite in Jiaodong Zhaoye district. Scientia Geologica Sinica 33, 318-328 (in Chinese with English abstract).

Hao, T.Y., Xu, Y., Suh, M, Xu, Y., Liu, J.H., Zhang, L.L., Dai, M.G., 2007. East marginal fault of the Yellow Sea: a part of the conjunction zone between Sino-Korea and Yangtze blocks? In: Zhai, M.-G., Windley, B.F., Kusky, T.M. \& Meng, Q.R. (eds), 2007. Mesozoic sub-continental lithospheric thinning under eastern Asia. Geological Society, London, Special Publications 280, 281-292. 
Hauser, E., Potter, C., Hauge, T., Burgess, S., Burtch, S., Mutschler, J., Allmendinger, R.W., Brown, L., Kaufman, S., Oliver, J., 1987. Crustal structure of eastern Nevada from COCORP deep seismic reflection data. Geological Society of America Bulletin 99, 833-844.

Hibbard, M., 1987. Deformation of incompletely crystallized magma systems: granitic gneisses and their tectonic implications. Journal of Geology 95, 543-561.

Hu, N., Zhao, D., Xu, B., Wang, T., 1995. Petrography and metamorphism study on highultrahigh pressure eclogite from Guanpo area, northern Qinling mountain. Journal of Mineralogy and Petrology 15, 1-9 (in Chinese with English abstract).

Hu, S., Fu, M., Yang, S., Yuan, Y., Wang, J., 2007. Palaeogeothermal response and record of Late Mesozoic lithospheric thinning in the eastern North China Craton. In: Zhai, M.-G., Windley, B.F., Kusky, T.M. \& Meng, Q.R. (eds), 2007. Mesozoic sub-continental lithospheric thinning under eastern Asia. Geological Society, London, Special Publications 280, 267-280.

Hu, J.M., Zhao, Y., Liu, X.W., 2009. Early Mesozoic deformations of the eastern Yanshan thrust belt, northern China. International Journal of Earth Sciences. doi 10.1007/s000531-0090417-5

Isaaks, E.H., Srivastava, R.M., 1989. Applied Geostatistics. Oxford University Press, New York. 
Jolivet, L., 2001. A comparison of geodetic and finite strain in the Aegean, geodynamic implications. Earth and Planetary Science Letters 187, 95-104.

Joly, A., Faure, M., Martelet, G., Chen, Y., 2009. Gravity inversion, AMS and geochronological investigations of syntectonic granitic plutons in the southern part of the Variscan French Massif Central. Journal of Structural Geology 31, 421-443.

Krige, D.G., 1951. A statistical approach to some basic mine valuation problems on the Witwatersrand. Journal of Chemistry, Metallogeny and Mining Society of South Africa 52, 119-139.

Lajaunie, C., Courrioux, G., Manuel, L., 1997. Foliation and 3D cartography in geology: principles of a method based on potential interpolation. Mathematical Geology 20, 571-584.

Li, Z.L., Yang, M.Z., 1993. The geology and geochemistry of gold deposits in Jiaodong region. Tianjin Science and Technology Press, 300p. (in Chinese).

Li, X.H., 2000. Cretaceous magmatism and lithospheric extension in southeast China. Journal of Asian Earth Science 18, 293-305.

Li, J.W., Vasconcelos, P.M., Zhang, J., Zhou, M.F., Zhang, X.J., Yang, F.H., 2003. ${ }^{40} \mathrm{Ar} /{ }^{39} \mathrm{Ar}$ Constraints on a temporal link between gold mineralization, magmatism, and continental margin transtension in the Jiaodong Gold Province, eastern China. The Journal of Geology $111,741-751$. 
Li, Z., Li, Y., Zheng, J.P., Han, D., 2007. Late Mesozoic tectonic transition of the eastern North China Craton: evidence from basin-fill records. In: Zhai, M.-G., Windley, B.F., Kusky, T.M. \& Meng, Q.R. (eds), 2007. Mesozoic sub-continental lithospheric thinning under eastern Asia. Geological Society, London, Special Publications 280, 239-266.

Lin, W., Wang, Q., 2006. Late Mesozoic extensional tectonics in the North China Block: a crustal response to subcontinental mantle removal? Bulletin de la Société Géologique de France 177, 287-294.

Lin, W., Faure, M., Monié, P., Wang, Q.C., 2007. Polyphase Mesozoic tectonics in the eastern part of the North China Blocks: insights from the Liaoning Peninsula massif (NE China). In: Zhai, M.-G., Windley, B.F., Kusky, T.M. \& Meng, Q.R. (eds), 2007. Mesozoic sub-continental lithospheric thinning under eastern Asia. Geological Society, London, Special Publications 280, 153-170.

Lin, W., Faure, M., Monié, P., Schärer, U., Panis, D., 2008. Mesozoic extensional tectonics in Eastern Asia: The South Liaodong Peninsula Metamorphic Core Complex (NE China). Journal of Geology 116, 134-154. doi: 10.1086/527456.

Lister, G.S., Banga, G., Feenstra, A, 1984. Metamorphic core complexes of Cordilleran type in Cyclades, Aegean Sea, Greece. Geology 12, 221-225.

Lister, G.S., Davis, G.A., 1989. The origin of metamorphic core complexes and detachments faults formed during Tertiary continental extension in the northern Colorado River region, USA. Journal of Structural Geology 11, 65-94. 
Liu, B., Wang, X., Cheng, J., Ying, H., 1994. Typical gold deposits in Jiaodong. In: Chen, B. (Ed.), New development of research on gold deposits of China 1-1, Chap. 4, Seismologic Publishing House, Beijing, 234-258 (in Chinese).

Liu, M., Cui, X., Liu, F., 2004. Cenozoic rifting and volcanism in eastern China: a mantle dynamic link to the Indo-Asian collision? Tectonophysics 393, 29-42.

Liu, J., Davis, G., Lin, Z., Wu, F., 2005. The Liaonan metamorphic core complex, southeastern Liaoning Province, North China: A likely contributor to Cretaceous rotation of eastern Liaoning, Korea and contiguous areas. Tectonophysics 407, 65-80.

Lü, G., Kong, Q., 1993. Geology of the Linglong-Jiaojia type gold deposits. Scientific Publishing House, Beijing, 253 p. (in Chinese).

Lu, S., Yang, C., Jiang, M., Li, H., Li, H., 1996. Evolution of Precambrian continent crust. Geological Publishing House, Beijing, 238 p. (in Chinese).

Lu, H.Z., Archambault, G., Li, Y., Wei, J., 2007. Structural geochemistry of gold mineralization in the Linglong-Jiaojia district, Shandong Province, China. Chinese Journal of Geochemistry 26, 215-234.

Luo, Z.K., Guan, K., Miao, L., Huang, J., 1999. The ages and its significance of inherited zircons in the granitoid in Zhaoyuan-Laizhou area. Geology of Shandong 3, 24-30 (in Chinese with English abstract). 
Lynch, H.D., Morgan, P., 1987. The tensile strength of the lithosphere and the localisation of extension. In: Coward, M.P., Dewey, J.F., Hancock, P.L. (eds), Continental extensional tectonics. Geological Society Special Publications 28, 53-65.

Ma, Z., 1997. The comprehensive interpretation report of the gravity and magmatic data in Shandong Province. Institute of prospection and geophysics of the Shandong Province.

Ma, Y., Cui, S., Wu, G., Wu, H., Zhu, D., Li, X., Feng, X., 1999. The structural feature of metamorphic core complex in Yiwulüshan mountains, West Liaoning. Acta Geoscientia Sinica 20, 385-391.

Malavieille, J., 1993. Late orogenic extension in the mountain belts: Insights from the Basin and Range and the Late Paleozoic Variscan Belt. Tectonics 12, 1115-1130.

Makris, J., 1978. The crust and upper mantle of the Agean region from deep seismic soundings. Tectonophysics 46, 269-284.

Mao, J., Wang, Y., Li, H., Pirajno, F., Zhang, C., Wang, R., 2008. The relationship of mantlederived fluids to gold metallogenesis in the Jiaodong Peninsula: evidence from D-O-C-S isotope systematics. Ore Geology Reviews 33, 361-381.

Martelet G., 1999. Modélisation de la structure crustale et du comportement mécanique de la lithosphère à partir des anomalies gravimétriques. Applications à l'Himalaya et au massif granitique du Mont-Lozère, Cévennes. PhD, Institut de Physique du Globe de Paris, pp.324. 
Martelet G., Calcagno, P., Gumiaux, C., Truffert, C., Bitri, A., Gapais, D., Brun, J.P., 2004. Integrated 3D geophysical and geological modelling of the Hercynian Suture Zone in the Champtoceaux area (South Brittany, France). Tectonophysics 382, 117-128.

Matheron, G., 1963. Principles of Geostatistics. Economic Geology 58, 1246-1268.

Meng, Q., 2003. What drove late Mesozoic extension of the northern China-Mongolia tract? Tectonophysics 369, 155-174.

Menzies, M.A., Fan, W.M., Zhang, M., 1993. Palaeozoic and Cenozoic lithoprobes and the loss of $>120 \mathrm{~km}$ of Archean lithosphere, Sino-Korean Craton, China, in: Prichard, H.M., Alabaster, T., Harris, N.B.W., Neary, C.R. (eds), Magmatic processes and plate tectonics, Geological Society, London, Special Publications 76, 71-81.

Menzies, M.A., Xu, Y.G., 1998. Geodynamics of the North China Craton, in: Flower, M.F.J., Chung, S.L., Lo, C.H., Lee, T.Y. (eds), Mantle dynamics and plate interaction in East Asia, American Geophysical Union, Washington D.C., Geodynamic series 100, 107-126.

Miao, L., Luo, Z., Guan, K., Huang, J., 1998. The implication of the SHRIMP U-Pb age in zircon to the petrogenesis of the Linglong granite, East Shandong Province. Acta Petrologica Sinica 14, 198-206 (in Chinese with English abstract).

Okay, A.I., Sengör, A.M.C., Satir, M., 1993. Tectonics of an ultrahigh-pressure metamorphic terrane: the Dabie Shan/Tongbai Shan orogen, China. Tectonics 12, 1320-1334. 
Passchier, C.W., Trouw, R.A.J., 2005. Microtectonics. Springer-Verlag, Berlin, $2^{\text {nd }}$ edition, 366p.

Paterson, S.R., Vernon, R.H., Tobisch, O.T., 1989. A view of criteria for the identification of magmatic and tectonic foliations in granitoids. Journal of Structural Geology 11, 349-363.

Paterson, S.R., Fowler, T.K., Schmidt, K.L., Yoshinobu, A.S., Yuan, E.S., Miller, R.B., 1998. Interpreting magmatic fabric patterns in plutons. Lithos 44, 53-82.

Qiu, Y.S., 1989. Regional geological setting of gold deposits in Zhaoye Gold Belt in Shandong Province. Liaolin Science and Technology Press, 153p. (in Chinese).

Ramsay, J.G., 1989. Emplacement kinematics of a granitic diapir: the Chinamora batholith, Journal of Structural Geology 11, 191-210.

Ratschbacher, L., Hacker, B.R., Webb, L.E., McWilliams, M., Ireland, T., Dong, S., Calvert, A., Chateigner, D., Wenk, H.R., 2000. Exhumation of the ultrahigh-pressure continental crust in east central China: Cretaceous and Cenozoic unroofing and the Tan-Lu fault. Journal of the Geophysical Research 105, 13303-13338.

Ratschbacher, L., Hacker, B.R., Calvert, A., Webb, L.E., Grimmer, J.C., McWilliams, M.O., Ireland, T., Dong, S., Hu, J., 2003. Tectonics of the Qinling (Central China): tectonostratigraphy, geochronology, and deformation history. Tectonophysics 366, 1-53. 
Ren, J., Tamaki, K., Li, S., Junxia, Z., 2002. Late Mesozoic and Cenozoic rifting and its dynamic setting in Eastern China and adjacent areas. Tectonophysics 344, 175-205.

Rey, P.F., Teyssier, C., Whitney, D.L., 2009. Extension rates, crustal melting, and core complex dynamics. Geology 37, 391-394.

Reynolds, S.J., Rehrig, W.A., 1980. Mid-Tertiary plutonism and mylonitisation, South Mountains, central Arizona. In: Crittenden, M.C., Coney, J.P., Davis, G.H. (eds), Cordilleran metamorphic core complexes. Geological Society of America Memoir, Boulder, 159-175.

Román-Berdiel, T., Aranguren, A., Cuevas, J., Tubía, J.M., 1998. Compressional granite emplacement model: structural and magnetic study of the Trives Massif (NW Spain). Lithos $44,37-52$.

Sang, L.K., 1984. The origin and evolution of the Linglong granites. Earth Sciences 9, 101114 (in Chinese).

SBGMR, 1991. Regional geology of the Shandong Province, Geological Memories, Ministry of Geology and Mineral Resources, People's Republic of China, Series 1, 26, Geological Publishing House, Beijing, 699 p. (in Chinese).

Simpson, C., Wintsch, R.P., 1989. Evidence for deformation-induced K-feldspar replacement by myrmekite. Journal of Metamorphic Geology 7, 267-275. 
Sokoutis, D., Brun, J.P., Van Den Driessche, J., Pavlides, S., 1993. A major Oligo-Miocene detachment in southern Rhodope controlling north Aegean extension. Journal of the Geological Society of London 150, 243-246.

Sun, W., Ding, X., Hu, Y.H., Li, X.H., 2007. The golden transformation of the Cretaceous plate subduction in the west Pacific. Earth and Planetary Science Letters 262, 533-542.

Talbot, J.Y., Martelet, G., Courrioux, G., Chen, Y., Faure, M., 2004. Emplacement in an extensional setting of the Mont-Lozère-Borne granitic complex (SE France) inferred from comprehensive AMS, structural and gravity studies, Journal of Structural Geology 26, 11-28.

Vanderhaeghe, O., 1999. Pervasive melt migration from migmatites to leucogranites in the Shuswap metamorphic core complex, Canada: control of regional deformation. Tectonophysics 312, 35-55.

Vigneresse, J.L., 1983. Enracinement des granites armoricains estimé d'après la gravimétrie. Bulletin de la Société Géologique de Minéralogie de Bretagne 15, 1-15.

Vigneresse, J.L., Brun, J.P., 1983. Les leucogranites armoricains marqueurs de la déformation régionale : apport de la gravimétrie. Bulletin de la Société Géologique de France 25, 357366.

Wan, T., Teyssier, C., Zeng, H., Zhou, W., Tikoff, B., 2001. Emplacement mechanism of Linglong granitoid complex, Shandong Peninsula, China. Science in China (Series D) 44, 535-544. 
Wang, L.G., Qiu, Y.M., McNaughton, N.J., Groves, D.I., Luo, Z.K., Huang, J.Z., Miao, L.C., Liu, Y.K., 1998. Constraints on crustal evolution and gold metallogeny in the Northwestern Jiaodong Peninsula, China, from SHRIMP U-Pb zircon studies of granitoids. Ore Geology Reviews 13, 275-291.

Wang, F., Zhou X.-H., Zhang, L.-C., Ying, J.-F., Zhang, Y.-T., Wu, F.-Y., Zhu, R.-X., 2006. Late Mesozoic volcanism in the Great Xing'an Range (NE China): Timing and implications for the dynamic setting of NE Asia. Earth and Planetary Science Letters 251, 179-198.

Webb, L.E., Graham, S.A., Johnson, C.L., Badarch, G., Hendrix, S., 1999. Occurrence, age, and implications of the Yagan-Onch Hayrhan metamorphic core complex, southern Mongolia. Geology 27, 143-146.

Wernicke, B., 1981. Low-angle normal faults in the Basin and Range Province: nappe tectonics in an extending orogen. Nature 291, 645-648.

Whitney, D.L., Teyssier, C., Vanderhaeghe, O., 2004. Gneiss domes and crustal flow. In: Whitney, D.L., Teyssier, C., Siddoway, C.S., Gneiss domes in orogeny: Boulder, Colorado, Geological Society of America Special Paper 380, 15-33.

Wilde, S.A., Zhou, X.H., Nemchin, A.A., Sun, M., 2003. Mesozoic crust-mantle interaction beneath North China craton: a consequence of the dispersal of Gondwanaland and accretion of Asia. Geology 31, 817-820. 
Wu, F.Y., Sun, D.Y., 1999. Mesozoic magmatism and lithospheric thinning in eastern China. Journal of Changchun Science and Technology University 29(4), 313-318 (in Chinese).

Wu, F.Y., Lin, J.Q., Wilde, S.A., Zhang, X.O., Yang, J.H., 2005a. Nature and significance of the Early Cretaceous giant igneous event in eastern China. Earth and Planetary Sciences Letters 233, 103-119.

Wu, F.Y., Yang, J.H., Wilde, S.A., Zhang, X.O., 2005b. Geochronology, petrogenesis and tectonic implications of Jurassic granites in the Liaodong Peninsula, NE China. Chemical geology 221, 127-156.

Wu, F.Y., Han, R.H., Yang, J.H., Wilde, S.A., Zhai, M.G., Park, S.C., 2007. Initial constraints on the timing of granitic magmatism in North Korea using U-Pb zircon geochronology. Chemical geology 238, 232-248.

Yang, M., Lü, G., 1996. The geology-geochemistry of gold deposits of the greenstone belt in Jiaodong district. Geological Publishing House, Beijing, pp.228 (in Chinese with English abstract).

Žalohar, J., Vrabec, M., 2007. Paleostress analysis of heterogeneous fault-slip data: the Gauss method. Journal of structural geology 29, 1798-1810.

Zhai, M.-G., Windley, B.F., Kusky, T.M. \& Meng, Q.R. (eds), 2007. Mesozoic subcontinental lithospheric thinning under eastern Asia. Geological Society, London, Special Publications 280. 
Zhao, Y., Yang, Z., Ma, X., 1994. Geotectonic transition from Paleoasian system and Paleotethyan system to Paleopacific active continental margin in Eastern China. Scientia Geologica Sinica 29, 105-119 (in Chinese with English abstract).

Zhang, Z.Q., Song, Z.Y., Zhang, S.F., Chi, S.X., 1994. New opinion on Precambrian strata of Ludong Province, Shandong province. Geology of Shandong 10, 14-26 (in Chinese).

Zhang, L.C., Shen, Y.C., Liu, T.B., Zeng, Q.D., Li, G.M., Li, H.M., 2003. ${ }^{40} \mathrm{Ar} /{ }^{39} \mathrm{Ar}$ and RbSr isochron dating of the gold deposits on northern margin of the Jiaolai Basin, Shandong, China. Science in China (Series D) 46, 708-718.

Zhang, Y.Q., Dong, S.W., Zhao, Y., 2008. Jurassic tectonics of North China: A synthetic view. Acta Geologica Sinica 82, 310-326.

Zhou, X.M., Li, W.X., 2000. Origin of Late Mesozoic igneous rocks in southeastern China: implications for lithospheric subduction and underplating of mafic magmas. Tectonophysics $326,269-287$.

Zhou, T., Lü, G., 2000. Tectonics, granitoids and Mesozoic gold deposits in East Shandong, China. Ore Geology Reviews 16, 71-90.

Zhou, X., Yang, J., Zhang, L., 2003. Metallogenesis of superlarge gold deposits in Jiaodong region and deep processes of subcontinental lithosphere beneath North China Craton in Mesozoic. Science in China (Series D) 46, 14-25. 
Zhou, X., Sun, T., Shen, W., Shu, L., Niu, Y., 2006. Petrogenesis of Mesozoic granitoids and volcanic rocks in South China: a response to tectonic evolution. Episodes 29, 26-33.

\section{Figure Captions:}

Figure 1: (a) Tectonic sketch map of eastern Asia. Sulu UHP B.: Sulu ultrahigh-pressure Belt, TNCB: Trans-North China Belt, TLF: Tan-Lu Fault. (b) Simplified geological map of Jiaodong Peninsula (Shandong Province). LL: Linglong massif, GJL: Guojialing massif.

Figure 2: Compilation of available geochronological data for the Linglong and Guojialing massifs. Four stages can be distinguished: (1) the granite crystallisation in the Linglong massif, (2) the granodiorite crystallisation and cooling in the Guojialing massif, (3) gold mineralization event and (4) late (post-tectonic) pinkish-reddish Cretaceous granodioritic pluton intrusions (e.g. Aishan granodiorite).

Figure 3: Ductile deformation in the Linglong and Guojialing massifs. (a) Reinterpretation of the Linglong and Guojialing massifs geological map with structural features measured in the field. Two main domains are discriminated: (1) the Linglong MCC (Late Jurassic granite and migmatites) intruded by Cretaceous isotropic granodiorites to the south, and (2) the Early Cretaceous deformed Guojialing synkinematic pluton to the north. Master MCC-type detachment fault (=LDF: Linglong detachment fault), extensional intracrustal shear zone (=GSZ: Guojialing shear zone) and brittle extensional faults with numerous Gold mines are localized on the map. (b) Field strain intensity measurements in Linglong MCC and Guojialing synkinematic pluton. Locations of the measurements are displayed with individual values by which the contours map is built up with kriging interpolation. In both massifs, 
interpolated strain maxima follow the trend of the shear zones: $\sim \mathrm{N} 30 \mathrm{E}$ for $\mathrm{LDF}$ and $\sim \mathrm{N} 30 \mathrm{E}$ for GZS. See Table 1 for details on the parameters used for interpolation. Late pinkish-reddish plutons are excluded to the computation.

Figure 4: Pictures of representative structures in the Linglong massif (see locations on Figure 5). $\mathrm{X}$ and $\mathrm{Y}$ values correspond to GPS geographic coordinates (WGS84). (a) Intrusive relationships between Archaean basement and granitic rocks. (b) Migmatites layering close to the Linglong detachment fault (LDF). (c) Polished hand specimen showing a C/S mylonite on the eastern border of the Linglong MCC with a top-to-N100E sense of shear. (d) Panorama of the southeastern Linglong MCC edge with eastward dipping foliation and LDF zone separating footwall mylonitic rocks and hanging wall rocks. (e) Photomicrograph of mylonite with polycrystalline quartz aggregates, K-feldspar d-type porphyroclast with a top-to-the $\mathrm{E}$ sense of shear. (f) Photomicrograph of a quartz-feldspar ultramylonite with K-feldspar d-type porphyroclast showing a top-to-the E kinematic on eastern border of the Linglong MCC. $(\mathrm{g})$ Low-angle shear zone (LASZ, fault plane=N102-14NE and L=N127E) cross-cut by late highangle brittle fault $(\mathrm{HABF}$, fault plane=N02-70E) in the Linglong massif. Pegmatites in granitic and migmatitic rocks are represented in grey color. (h) General view of the cataclastic fabric associated with fluids circulation during brittle deformation in the Linglong MCC ("fault" plane=N178-33E), and detailed view on breccias.

Figure 5: Structural cross-sections in the Linglong massif with diagrams of strain intensity modelling (Fig. 3b) and occurrence of brittle structures. (a) Strain localisation toward the Linglong detachment fault on the eastern border of the Linglong MCC. (b) Reworking of the Linglong detachment fault by brittle deformation coeval with gold mineralizations. Locations 
of pictures of Figure 4 are marked on cross-sections. (*) indicates data measured out of the section. $\mathrm{LDF}=$ Linglong Detachment Fault, GSZ $=$ Guojialing shear zone.

Figure 6: Field evidences of deformation evolution in the Guojialing massif. (a) Isotropic Guojialing granodiorite. (b) Polished hand specimen showing a moderate C/S fabric in the Guojialing pluton inside the Guojialing shear zone showing a top-to-the NW kinematic (L=N130E). (c) Tracing of a photograph showing a strong C/S fabric with a top-to-the NW kinematic (L=N132E). (d) Photomicrograph of recrystallised quartz aggregates showing solid-state deformation in mylonitic rocks of the Guojialing pluton. (e) Field structural crosssection in the Guojialing massif with diagram of strain intensity modelling (Fig. 3b) toward the extensional Guojialing intracrustal shear zone. GSZ = Guojialing shear zone. qz: quartz, bi: biotite.

Figure 7: State of palaeostress related to brittle deformation in the Linglong MCC and the Guojialing synkinematic pluton. (a) Microtectonic sites illustrated by equal-area stereoplots show a NW-SE extensional event (black solid squares and large solid arrows) and also a NNE-SSW one (grey solid squares and large solid arrows); solid squares and large solid arrows correspond to computed axes $\left(\sigma_{1}, \sigma_{2}, \sigma_{3}\right)$ and directions of horizontal extension and/or compression, respectively; (b) distribution map of microtectonic sites used to study palaeostress regimes in the study area. Quality of computed palaeostress directions using TTECTO 2.0 software (Žalohar and Vrabec, 2007) is represented by grey scale arrows (A = well-defined in black, $\mathrm{B}=$ quite well-defined in grey and $\mathrm{C}=$ poorly defined in white). Big arrows are used to represent the NW-SE extensional event while small ones for NNE-SSE extensional event. Rose diagram of slickenside lineations directions shows a N120E mean orientation in the Linglong MCC and Guojialing synkinematic pluton. 
Figure 8: Gravity study in the Linglong and Guojialing massifs. (a) Bouguer anomaly map of the study area (values in $10^{-5} \mathrm{~m} / \mathrm{s}^{2}$, after Ma, 1997), (b and c) measured Bouguer anomaly cross-sections (dotted lines on map) with modelling of deep structures geometry. * Densities of materials issued from Wan et al. (2001), ** densities of materials measured in laboratory (this study).

Figure 9: Reconstruction of evolution of the Linglong and Guojialing Massifs in main steps. 3D block-diagram are constrained by 3D models computed using the 3D GeoModeller software (@Intrepid-BRGM). (a) Prior to 130 Ma: exhumation of the Linglong Metamorphic Core Complex below the Linglong detachment fault zone (LDF). (b) 130-124 Ma: emplacement of the Guojialing syntectonic pluton roofed by the Guojialing intracrustal shear zone (GSZ). (c) Reworking of previous ductile structures by brittle deformation and gold mineralizations event, followed by intrusion of Cretaceous granodiorites. (d) Sketch of the southern limb of the Linglong MCC. Italic numbers noted in the lithology column indicate the qualitative scale of deformation strain estimated in the field. See the text for further details. LDF = Linglong detachment fault, GSZ = Guojialing shear zone. (e) Differences in term of strain amount: MCC vs. synkinematic pluton. MCC exhumation implies a stronger amount of extension undergone by crust than synkinematic pluton emplacement.

Table 1: Semi-variogram models used for the ordinary kriging interpolation of the strain field intensity measured within the Linglong and Guojialing massifs.

Table 2: Results of palaeostress analyses in the Linglong and Guojialing massifs. n: the total fault planes measured for each site to calculate palaeostress direction; $\sigma_{1}, \sigma_{2}$ and $\sigma_{3}$ : principal 
stress axes with their strike and dip in degrees $\left(\sigma_{1}>\sigma_{2}>\sigma_{3}\right)$; $\Phi$ : the ratio of principal stress magnitudes $\left(\Phi=\left(\sigma_{2}-\sigma_{3}\right) /\left(\sigma_{1}-\sigma_{3}\right)\right)$; Misfit angle expressed in degrees represents the quality of computed palaeostress directions; Quality: A = very good fault-striae data set, B = good fault striae data set and $\mathrm{C}=$ regular fault striae data set. Linglong dome $(\mathrm{G}=\mathrm{Granite}+$ M=Migmatites), GJL=Guojialing pluton, $\mathrm{Br}=$ Breccias. See the text for further explanations. 